\title{
Model Teologi Gereja di Abad XXI: Studi Arah Pengembangan menuju Globalisasi
}

\author{
Harianto GP \\ Ketua Sekolah Tinggi Teologi Excelsius \\ hariantogp@sttexcelsius.ac.id
}

\begin{abstract}
The model (shape, style, paradigm or style) is the most important part of seeing a development, especially the theological church. Theology here is not only interpreted as "knowledge (cognitive) about God" but also changes in the affective and psychomotor of the church towards the knowledge of God. The Church is responsible for laying the cognitive foundation of God and making changes within himself and having the skills to worship and carry out His will. In this context the term "Church Theological Model" appears. The author conducts research based on models of church theology which began from the time of the fathers of the Church to the Church of the XX century. From there it can then be arranged in the direction of development towards globalization which reaches in the direction of the models of Church theology in the Indonesian Churches.
\end{abstract}

Keywords: Model; Theology; Church; Globalization; Indonesia

\begin{abstract}
Abstrak
Model (bentuk, corak, paradigm atau gaya) merupakan bagian terpenting dalam melihat sebuah perkembangan, khususnya gereja berteologi. Teologi di sini bukan saja diartikan sebagai "pengetahuan (kognitif) tentang Tuhan" tetapi juga perubahan afektif dan psikomotoris gereja terhadap pengetahuan akan Tuhan tersebut. Gereja bertanggungjawab untuk meletakan dasar kognitif akan Tuhan dan melakukan perubahan di dalam diri serta mempunyai keterampilan menyembah dan melaksanakan kehendak-Nya. Dalam konteks ini muncul istilah "Model Teologi Gereja". Penulis melakukan penelitian berdasarkan model-model teologi gereja yang dimulai sejak masa bapa-bapa Gereja hingga Gereja masa abad XX. Dari situ kemudian bisa tersusun arah pengembangan menuju globalisasi yang mencapai pada hasil arah model-model teologi Gereja di Gereja-gereja Indonesia.
\end{abstract}

Kata Kunci: Model; Teologi; Gereja; Globalisasi; Indonesia 


\section{PENDAHULUAN}

Model Teologi Gereja berkembang, yang bermuara dari tanah Israel hingga ke Eropa, Amerika dan seluruh dunia termasuk Indonesia. Asalnya teologi tersebut (kekristenan itu) dimulai di kota Yerusalem dan mulai menyebar ke wilayah Timur Dekat, termasuk ke Siria, Asyur, Mesopotamia, Fenisi, Asia Minor, Yordania dan Mesir. Pada abad ke-4 kekristenan telah dijadikan agama negara oleh Dinasti Arsakid di Armenia pada tahun 301, "Caucasian Iberia" (atau Republik Georgia) pada tahun 319, Kekaisaran Aksum di Etiopia pada tahun 325 dan Kekaisaran Romawi pada tahun 380 M. Sekitar 15 tahun setelahnya kekristenan mulai memasuki Eropa Selatan dan berkembang di sana. Sementara itu juga terjadi penyebaran di Afrika Utara, Asia Selatan dan Eropa Timur. Abad Pertengahan mengembang ke seluruh dunia selama Masa Eksplorasi negara-negara Eropa dari zaman Renaissance sampai menjadi agama terbesar di dunia. Sekarang terdapat lebih dari 2 miliar orang Kristen, yaitu sepertiga jumlah manusia di dunia.

Tujuan artikel ini menjawab beberapa pertanyaan sebagai berikut: Bagaimanakah model-model Teologi gereja yang sudah didigunakan oleh gerejagereja? Sejauhmanakah para hamba Tuhan meresponi model-model teologi gereja?
Bagaimanakah evalusi model-model teologi gereja bagi para hamba Tuhan?

\section{METODE PENELITIAN}

Artikel ini ditulis mengacu pada hasil penelitian dengan menggunakan metode studi pustaka dan kualitatif (wawancara). Penulis menggali berbagai informasi tentang model-model teologi gereja dan perkembangannya dari bukubuku. Selain itu, penulis juga mencoba melakukan penelitian awal dengan metode kualitatif berdasarkan dari 42 partisipan yang diwakili berbagai sinode gereja.

\section{ANALISIS DAN HASIL PENELITIAN}

Masa Bapa-bapa Gereja hingga Tahun $\underline{1500}$

Masa Bapa-bapa Gereja sampai Tahun $500 \mathrm{M}$-- yang munculkan tokohtokoh dari Platinisme, Tertulianus, Pengakuan Imam Rasuli, Konsili Konstantinopel (553), Maximus Sang Syahid, Konsili Konstantinopel (680-681), Pengakuan Iman Athanasius, Boethius, Gregorius Agung, Konsili Firenze (14381445) hingga Gambriel Biel memunculkan beberapa model teologi gereja sebagai berikut:

Model Gereja Berteologi Berbasis Filsafat Model Teologi Gereja Berbasis Filsafat. Munculnya model ini dikarena karya-karya yang dilahirkan oleh seorang 
Origenes. Dari meja kerja sebagai seorang ilmuwan Origenes mempengaruhi gerejagereja dalam memutuskan teologinya berdasarkan pendidikan. Keilmuwaan Origenes menjadi model teologi gereja.

\section{Ajaran Model Teologi Origenes}

Origenes dipengaruhi oleh filsuffilsuf Yunani seperti Plato. Dari sana ia mengajarkan ajaran-ajaran yang oleh gereja dianggap salah. Ia mengajarkan bahwa: (1) dari awal semua makhluk yang rasional mulanya adalah berupa roh. (2) setelah penebusan dosa melalui penyaliban Yesus di kayu salib maka baik orang yang telah masuk neraka juga akan ditebus dosanya dan kembali menjadi suci dan percaya bahwa jika orang sudah berada di surga dan melakukan pelanggaran di sana akan dikeluarkan dari surga. Gereja mempercayai orang yang masuk neraka telah kehilangan kesempatan untuk bertobat, sehingga dosanya tidak terampuni lagi. Demikian juga orang yang sudah masuk surga tidak dapat berbuat dosa lagi sehingga kembali berdosa, sebab jika demikian maka neraka dan surga tidak ubahnya seperti dunia.

Model Teologi Gereja Berbasis Pertobatan Orang Murtad Model Teologi Gerja Berbasis Pertobatan Orang Murtad. Petobat-petobat pertama kepada kekristenan adalah orangorang Yahudi atau penganut-penganut
Yudaisme dan gereja, yaitu "persekutuan orang-orang yang mengaku Ketuhanan Yesus", berpusat di Yerusalem. Mereka berpaling dari kehidupan tradisi masuk dalam persekutuan orang-orang Kristen. Mereka memberitakan Yesus sebagai Mesias atau Juruselamatnya orang Yahudi. Sebenarnya model ini klasik di mana banyak orang-orang yang berdosa bahkan murtad bertobat menjadi pengikut Kristus seperti: Saulus menjadi Paulus. Tetapi dalam konteks ini, pertobatan orang berdosa menjadi satu model yang dilegalkan oleh gereja. Ajaran Model Berteologi Siprianus: (1) semakin besar dosa seseorang, maka ia semakin lama pula masa penyesalannya. Idenya mendapat sambutan dan menjadi disiplin Gereja paling kuat pada waktu itu. Gereja menjadi sarana penebusan dosa. (2) Siprianus tidak setuju dengan adanya orang-orang murtad dikeluarkan dari gereja. Justru orang murtad yang bertobat -- misalnya kaum homo dan lesbi yang bertobat - akan menjadi saksi Kristus yang setia. Jadi gereja wajib memasuki mereka sebagai anggotanya. (3) Orang percaya sejati harus menjalani hukuman untuk menebus dosa, untuk membuktikan imannya. Pada tahun 251, Siprianus mengadakan konsili di Kartago. Di depan tokoh agama, ia membacakan karyanya, "Persatuan di dalam gereja". Karyanya itu terkenal dan yang sangat berpengaruh dalam sejarah 
gereja. Gereja, katanya, adalah lembaga ilahi, yaitu mempelai Kristus, dan hanya ada satu mempelai. Hanya di dalam gereja manusia akan mendapatkan keselamatan, di luar itu yang ada hanyalah kegelapan dan kebingungan. Di luar gereja, sakramen dan para rohaniwan - bahkan Alkitab - tidak ada artinya. Seseorang, secara pribadi, tidak dapat menjalankan kehidupan Kristen melalui kontak langsung dengan Allah; ia membutuhkan gereja.Dengan diterimanya ide ini, tentu saja, para Uskup mendapatkan kuasa lebih besar. (4) Ia mencetuskan ide bahwa misa adalah pengorbanan tubuh dan darah Kristus. Karena para imam menjalankan fungsinya dalam ibadah atas nama Kristus, maka hal ini pun meningkatkan kuasa mereka.

\section{Model Teologi Gereja Berbasis Politik}

Gereja pada abad pertengahan mempunyai model berteologi berbasis politik. Masa ini dimulai sejak berakhirnya kekuasaan Kaisar Romawi Barat hingga diganti oleh Kaisar Charlemagne sebagai Kaisar Eropa Barat (tahun 476-800). Pada masa ini gereja, terutama Kepausan, mengalami kemunduran moral. Para Paus dipaksa untuk terlibat lebih dalam lagi dalam politik, yang seringkali kotor dan harus mengimbangi keinginan Kekaisaran

${ }^{1}$ John H. Yoder, The Politics of Jesus (Grand Rapids: William B. Eerdmans Publishing Company, 1979), 135-136.
Romawi Timur dan pemerintahan bangsa barbar di Barat.

John Yoder pernah menulis bahwa Yesus adalah kekuasaan. Kekuasaan ini adalah kunci menyelesaikan segala revolusi yang munculkan dalam segala kehidupan social. ${ }^{1} \quad$ Selanjutnya, Song mengartikan salib sebagai titik penderitaan mesias, tetapi ia juga mempunyai istilah "Politik Salib". Bagi Song, dalam menjawab keadaan dunia yang semakin keras dan menindas, ia tidak saja menawarkan "mesias yang menderita", "salib yang menderita", tetapi juga memberi alternatif lain, adalah "Politik Salib". Politik Salib adalah politik yang paling tepat bagi Yesus dan pengikutpengikut-Nya yang setia. Politik Salib ini menggeser politik rakyat $^{2}$ atau dimulai dengan politik rakyat dan akhirnya harus menuju ke politik Salib. Dalam nama Salib, orang-orang Kristen memberikan kesaksian tentang Allah yang pengasih dan penyayang kepada dunia yang penuh kebencian dan konflik.Kekuatan yang diperlihatkan oleh politik salib adalah kekuasaan yang efektif dari kesaksian iman. Inilah kekuasaan yang menuntut siapa saja yang memerintah dengan serakah dan tidak adil. Inilah kekuasaan yang memberikan tentang baru dan pengharapan

\footnotetext{
${ }^{2}$ Politik yang digerakkan oleh rakyat dengan kekuatan yang bersumber pada rakyat.
} 
baru. Dan inilah kekuasaan yang memeliharakan visi umat manusia agar tetap terarah kepada segala yang baik, yang benar, yang indah. Salib, meminjam katakata Rasul Paulus, adalah "kekuatan dan hikmat Allah". Ia adalah dasar etika politik Kristen. Dan ia adalah inti kekuatan etika Kristen. Salib telah dan akan selalu menjadi pusat teologi politik. ${ }^{3}$

Model Teologi Gereja Berbasis Pendidikan Ajaran Model Gereja Berteologi Berbasis Pendidikan: menjadikan semua manusia khusus rakyat jelatah berpendidikan. Pendidikan membukakan masa depan seseorang untuk semakin berhasil. Pendidikan menuntun masyarakat melek segalanya sehingga mereka bergerak pada tingkatan pemikiran yang lebih tinggi dan lebih tinggi lagi. Ketika masyarakat menjadi pintar maka mereka mulai dapat melihat sebuah kebaikan atau keburukan.

\section{Masa Reformasi dan Reaksi 1500-1800}

Masa Reformasi dan Reaksi 15001800 - dari muncullahnya tokoh-tokoh seperti: Desiderius Erasmus, Tradisi Lutheran, Tradisi Calvinis hingga Blaise Pascal. Dari mereka inilah muncul modelmodel teologi gereja sebagai berikut:

\footnotetext{
${ }^{3}$ Choan-Seng Song, Sebutkanlah Namanama Kami (Jakarta: Gunung Mulia, 1989), 238.

${ }^{4}$ St. Clement of Rome, Letter to the Corinthians, chap. 46, seperti dikutip oleh John
}

Model Teologi Gereja Berbasis Ajaran Trinitas

Berteologi berdasarkan Ajaran Trinitas: hanya ada satu Allah saja, yaitu Bapa, yang dari pada-Nya berasal segala sesuatu dan yang untuk Dia kita hidup, dan satu Tuhan saja, yaitu Yesus Kristus, yang oleh-Nya segala sesuatu telah dijadikan dan yang karena Dia kita hidup" (1 Kor. 8:6). Prinsip dasar Allah Trinitas sudah diajarkan oleh para rasul dan para penerus mereka yaitu para Bapa Gereja, sebelum abad ke-4. Berikut ini kutipannya: (1) St. Paus Clement dari Roma (menjadi Paus tahun 88-99): "Bukankah kita mempunyai satu Tuhan, dan satu Kristus, dan satu Roh Kudus yang melimpahkan rahmat-Nya kepada kita?"4 (2) St. Ignatius dari Antiokhia (35-107) membandingkan jemaat dengan batu yang disusun untuk membangun bait Allah Bapa; yang diangkat ke atas oleh 'katrol' Yesus Kristus yaitu Salib-Nya dan oleh 'tali' Roh Kudus. "Ignatius, juga disebut Theoforus, kepada Gereja di Efesus di Asia... yang ditentukan sejak kekekalan untuk kemuliaan yang tak berakhir dan tak berubah, yang disatukan dan dipilih melalui penderitaan sejati oleh Allah Bapa di dalam Yesus Kristus Tuhan kita."6 (3) St. Agustinus (354-430), “...

Willis SJ, The Teachings of the Church Fathers (San Francisco: Ignatius Press, 2002), 145.

${ }^{5}$ St. Ignatius of Antiokh, Letter to the Ephesians, Chap 9, 146.

${ }^{6}$ St. Ignatius, Letter to the Ephesians, 110. 
Allah Bapa dan Putera dan Roh Kudus adalah kesatuan ilahi yang erat, yang adalah satu dan sama esensinya, di dalam kesamaan yang tidak dapat diceraikan, sehingga mereka bukan tiga Tuhan, melainkan satu Tuhan: meskipun Allah Bapa telah melahirkan (has begotten) Putera, dan Putera lahir dari Allah Bapa, Ia yang adalah Putera, bukanlah Bapa, dan Roh Kudus bukanlah Bapa ataupun Putera, namun Roh Bapa dan Roh Putera; dan Ia sama (co-equal) dengan Bapa dan Putera, membentuk kesatuan Tritunggal."

\section{Model Teologi Gereja Berbasis Keagamaan Murni \\ Model Gereja berteologi berbasis} keagamaan murni (Alkitab) terjadi pada masa pergerakan Lutheran. Masa ini disebut masa "Reformasi Protestan". Masa ini diwarnai oleh tokoh-tokoh yang membawa pembaruan dalam gereja Katolik Roma (tahun 1517- 1600). Tokoh-tokoh Reformasi seperti: Martin Luther, Yohanes Calvin, dan John Knox pada akhirnya mengakhiri dominasi para uskup dan biarawan dalam mempelajari Alkitab. Reformasi Protestan menyebabkan KontraReformasi dan reformasi lainnya di Eropa Barat, sementara penemuan benua Amerika menyebabkan kaum Protestan yang dianiaya di Eropa, terutama Inggris, melarikan diri ke Amerika dan memulai negara baru yang berlandaskan kekristenan. Dalam waktu seratus tahun, terjadi lebih banyak peristiwa-peristiwa penting dari abad-abad sebelumnya, dan seluruh Eropa Barat terancam perang saudara.

Ajaran Model Berteologi Luther: Ajaran khas Martin Luther yang seringkali juga diakui sebagai ciri khas ajaran Reformasi disimpulkan dalam tiga sola, yaitu "sola fide" (hanya iman), "sola gratia" (hanya anugerah) dan "sola scriptura" (hanya Kitab Suci)". Berkaitan tiga "sola" di atas, Luther menyatakan bahwa keselamatan manusia hanya diperoleh karena imannya kepada karya anugerah Allah yang dikerjakannya melalui Yesus Kristus: "Sebab karena kasih karunia kamu diselamatkan oleh iman; itu bukan hasil usahamu, tetapi pemberian Allah,itu bukan hasil pekerjaanmu: jangan ada orang yang memegahkan diri” (Ef. 2: 8-9).

Luther menentang praktek penyalahgunaan "indulgensia" (penghapusan hukuman sementara akibat “dosa”) pada saat itu. Ia menyatakan bahwa manusia diselamatkan bukan karena amal atau perbuatannya yang baik, melainkan semata-mata oleh karena anugerah Allah. Hal ini didasarkan pada perkataan Paulus: "Akan tetapi Allah menunjukkan kasih-Nya kepada kita, oleh karena Kristus telah mati untuk kita, ketika kita masih berdosa" (Rm. $5: 8)$. 
Model Teologi Gereja Berbasis Misioner

Pada tahun 1790-1900, gereja Protestan (Reformasi) memperlihatkan minat yang luar biasa pada pekerjaan misi. Inilah "Asal Usu; untuk pengutusan Injil Protestan”. William Carey, seorang yang disebut sebagai "bapa misi protestan". Ada empat gerakan yang merubah gereja menjadi gereja amisioner adalah: Puritan, Piestis, Moravian dan Wesleyan. Keempat gerakan ini mempengaruhi pembaharuan denominasi Protestan di seluruh Eropa dan Amerika dan pembaharuan tersebut berbuah: "Pengutusan Injil".?

Ajaran Model Teologi Gereja Berbasis Misioner: "Pergilah, jadikanlah semua bangsa murid-Ku dan baptislah mereka dalam nama Bapa dan Anak dan Roh Kudus, dan ajarlah mereka melakukan segala sesuatu yang telah Kuperintahkan kepadamu. Dan ketahuilah, Aku menyertai kamu senantiasa sampai kepada akhir zaman" (Mat. 28: 19-20).

\section{$\underline{\text { Pemikiran Kristen di Dunia Modern }}$ $\underline{\text { Setelah Tahun } 1800}$}

Pemikiran Kristen di Dunia Modern Setelah Tahun 1800 - yang memunculkan tokoh-tokoh Kaum Liberal, Kelompok Evangelikal, Teolog Evangelikal Gerakan Pentakostal dan Karismatik, Ortodoksi Baru, para Eksistensialis hingga Dewan

${ }^{7}$ John Culver, Sejarah Penginjilan Sedunia (Bandung: Institut Alkitab Tiranus, 1997), 49.
Gereja-gereja se-Dunia muncul modelmodel teologi gereja sebagai berikut:

$$
\begin{gathered}
\text { Model Teologi Gereja Berbasis Teologi } \\
\text { Reformed }
\end{gathered}
$$

Ajaran Model Teologi Gereja Reformed: Gereja Reformed memiliki motto ecclesia reformata semper reformanda secundum verbum Dei atau "gereja yang telah tereformasi harus terus bereformasi sesuai dengan firman Tuhan". Ada lima ajaran Calvin yang disebut “TULIP adalah: (1) Total depravity (Kerusakan total). (2) Unconditional election (Pemilihan tanpa syarat). (3) Limited atonement (Penebusan terbatas). (4) Irresistible grace (Anugerah yang tidak dapat ditolak). (5) Perseverance of the saints (Ketekunan orang-orang kudus).

Model Teologi Gereja Berbasis Pentakosta Ajaran Model Gereja Berteologi Berbasis Pantekosta: (1) Authority. Seperti halnya Protestan konservatif, kaum Pentakosta dengan suara bulat mengenalkan diri mereka berdasarkan biblika (alkitabiah). "Ini biblika yang tidak dikombinasikan dengan satu pemahaman historis dan kritis Alkitab." Bahkan Pentakosta studi dari bahasa-bahasa yang asli (Ibrani, Aram, Yunani) dari Alkitab dalam satu usaha untuk munculkan makna 
teks Alkitab. Meskipun berdasarkan alkitabiah, mereka juga mengaku diri seorang Injili - berorientasi memenangkan sebanyak mungkin jiwa-jiwa yang sesat. Pada waktu yang sama, dalam praktek, banyak kaum Pentakosta mempunyai suatu sangat subjektif dan konsep yang experiential dari otoritas. "Tuhan mengatakan kepada aku" adalah suatu ciri khas otoritas Allah kepada orang-orang Pentakosta dalam menjalankan tugas yang diberikan kepada Allah. Nubuatan adalah suatu sangat dihormati untuk dijalankan dan hal tersebut merupakan dari ketundukan akan otoritas Alkitab. (2)

Doctrin of God. Kebanyakan kaum Pentakosta berpaut pada doktrin kaum ortodox yang tradisional dari Tritunggal sebagai yang dinyatakan oleh para leluhur (bapa-bapa) Gereja dalam sejarah. Kaum Pentakosta percaya Tritunggal - Allah Bapa, Anak dan Roh Kudus. Ketiganya adalah satu oknum, yang tidak dapat dipisah-pisahkan. Dengan demikian baptisan dinyatakan dalam nama "Allah Bapa, Anak (Yesus Kristus) dan Roh Kudus”. Baptisan menjadi sah bila dalam nama Tritunggal (Mat 28:19). Karena itu, banyak gembala terkemuka menanggalkan baptisan yang terdahulu dan mereka dibaptis kembali dalam nama Yesus. (3) Spiritual gifts. Kaum Pentakosta percaya bahwa karunia dari 1 Korintus 12: 8-10 adalah kehidupan mereka sehari-hari.
Baptisan di dalam Roh Kudus melengkapi berbagai karunia dalam kehidupan orang percaya. Berbicara dengan bahasa lidahlidah, tentu saja, menduduki posisi yang pertama bagi kehidupan beribadah orangorang Pantekosta. Meskipun untuk dapat berbahasa lidah harus dibaptis dalam Roh. Pada awalnya, tidak ada pembedaan dibuat antara bahasa lidah sebagai suatu tanda dan bahasa lidah sebagai suatu karunia rohani. Kepercayaan baptisan Roh itu dibawa suatu karunia dari kuasa. Tetapi beberapa tahun terakhir, mereka sedang meminta dengan tegas perlunya ada pembedaan antara bahasa lidah sebagai awal dari baptisan (Kis. 2:4) dan sebagai karunia rohani (1 Kor. 12:30).

Model Teologi Gereja Berbasis Karismatik Ajaran Model Teologi Gereja Berbasis Karismatik: Gerakan Karismatik memiliki banyak kemiripan dengan aliran Pentakosta, dan perkembangan aliran Pentakosta tampaknya tidak akan pernah terlepaskan dalam topik perkembangan Karismatik. Pengaruh aliran Pentakosta terhadap gerakan Karismatik tidak dapat dipungkiri. Keduanya mengakui "kuasa Roh Kudus". Kesembuhan Ilahi telah diterima secara meluas di antara kedua Gerakan, dan keduanya dikenal dengan gaya khotbah yang berai-api.

Walau demikian, ada juga banyak perbedaan yang memisahkan secara tajam 
Karismatik dari Pentakosta sebagai berikut:

(1) Kebanyakan Karismatik menolak keutamaan glossolalia yang diberlakukan oleh Pentakosta. (2) Kebanyakan Karismatik menolak beberapa ajaran Pentakosta yang dianggap legalisme oleh Karismatik. (3) Kebanyakan Karismatik seringkali tetap berada di denominasinya sendiri, tidak mendirikan gereja baru, contohnya Karismatik Katolik di Gereja Katolik Roma. (4) Perbedaan di antara keduanya juga bisa dilihat dari gaya dan tata ibadah (misalnya cara penyembahan, cara berkhotbah, dan metode pelayanan altar). (5) Aliran Pentakosta lahir jauh lebih dahulu daripada Gerakan Karismatik. (6) Karena kemiripannya, pada masa kini semakin lama semakin sulit untuk membedakan Karismatik dan Pentakosta sebagai gerakan yang terpisah. Tetapi karena tidak satu pun gerakan tersebut yang monolitik, maka juga sulit untuk menyatakan mereka sebagai gerakan yang sama.

\section{Model Teologi Gereja Berbasis}

Oikumenisme

Ekumenisme (oikoumenisme, oikumenisme) berasal dari bahasa Yunani oikos (rumah) dan menein (tinggal). Oikoumene berarti "rumah yang ditinggali" atau "dunia yang didiami". Dalam

\footnotetext{
${ }^{8}$ Joppy A. Saerang, "Oikumene dan Pemahamannya menurut Alkitab"; Jurnal Pelita Zaman Vo. 1 Th. 1 (1986).
}

pengertiannya yang paling luas, ekumenisme berarti inisiatif keagamaan menuju keesaan di seluruh dunia. Tujuan yang lebih terbatas dari ekumenisme adalah peningkatan kerja sama dan saling pemahaman yang lebih baik antara kelompok-kelompok denominasi di dalam agama yang sama.

Usaha-usaha oikumenis telah dijajaki oleh gereja-gereja anggota PGI untuk terwujudnya gereja Kristen yang esa di Indonesia. Gerakan itu menjadi satu mode dalam suatu kegiatan di antara beberapa gereja. Jiwa Oikumenis sering diungkapkan dengan mengadakan suatu perayaan hari besar Kristen, seperti: Paskah dan Natal bersama dan sebagainya, sehingga ada sebagian orang mengidentikkan kegiatan secara bersamasama itulah Oikumene. Segala usaha berupa pertemuan, konsultasi, rapat dan mengadakan proyek secara bersama-sama itu sudah menyatakan kesadaran Oikumenis. Di sini jelas kesadaran Oikumenis hanya dilihat secara lahiriah berupa kegiatan-kegiatan. ${ }^{8}$

\section{Gereja Masa Abad XX}

Gereja masa abad 20 telah menuju pada pengembangan model yang lebih luas dan terjadi pada kelompok-kelompok aliran 
yang besar seperti Protestan, Pantekostal dan Karismatik. Model teologi gereja sebagai berikut:

\section{Model Teologi Gereja Berbasis}

Pendidikan sebagai Proses Jemaat Berteologi

Model Teologi Gereja Berbasis Pendidikan sebagai Proses Jemaat Berteologi berupa adalah: (1) "Kelompok Pemahaman Alkitab"9 atau SOM (Sekolah Orientasi melayani). Proses pendidikan dibutuhkan untuk menyelidiki seluruh doktrin Alkitab, kebenaran Alkitab yang tak pernah berubah itu, untuk mengevaluasi doktrin-doktrin yang telah menjadi tradisi denominasi-denominasi gereja Barat, yang selama ini disebut sebagai kepercayaan ortodoks, tetapi tidak sesuai dengan kebenaran Alkitab. (2) Dosen seminari dan pemimpin gereja perlu membentuk kelompok kecil untuk mempelajari rencana pembangunan nasional. Berdasarkan kebenaran Alkitab, dengan sikap positif meresponinya, serta mendorong orang Kristen turut berperan serta di berbagai sektor pembangunan nasional. (3) Dosen seminari perlu menyelidiki baik buruknya pemikiran, motivasi, langkah-langkah dan penafsiran. (4) Perlu adanya kerja sama antara seminari dan gereja setempat untuk membentuk pendidikan teologi kaum

${ }^{9}$ Peter Wongso, Hamba Tuhan dan jemaat Kristus yang Melintasi Zaman (Malang: SAAT, 2002), 7-23.

${ }^{10}$ Ibid. awam, di mana dosen teologi dan orang Kristen awam dapat berinteraksi secara langsung selaku guru dan sahabat. (6) Setiap minggu gembala sidang atau hamba Tuhan harus berusaha untuk menulis artikel-artikel yang bersifat penelitian dan sistematis, atau mengundang orang Kristen yang pandai dalam kesusasteraan untuk menulisnya. Kemudian dimuat dalam

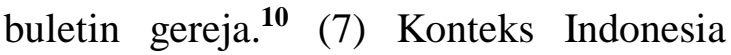
menuntut bahan-bahan pengajaran iman yang relevan dengan konteks Indonesia. Bahan ajar itu disusun sendiri sebagai wujud dari kemandirian (berteologi).

Model Teologi Gereja Berbasis Tridarma Gereja

Model Teologi Gereja Berbasis "Tridarma Gereja". Tridarma adalah: Koinonia (Persekutuan), Marturia (Kesaksian) dan Diakonia (Pelayanan). ${ }^{11}$ Dalam perkembangan kemudian di dalam gereja-gereja Protestan Tridarma ini sangat dipengaruhi oleh tekanan pada pemberitaan firman Allah sebagai satu-satunya hal yang penting dan mendasar. Batas-batas Tridarma akhirnya menjadi kabur dan ditentukan oleh pemberitaan firman. Koinonia merupakan persekutuan di sekitar firman Allah, marturia dipersempit menjadi kesaksian yang berkaitan dengan kebenaran

\footnotetext{
${ }^{11}$ E.G.Singgih, "Hakikat Gereja yang Melayani" dalam Reformasi dan Transformasi Pelayanan Gereja Menyongsong Abad ke-21 (Yogyakarta: Kanisius, 1997), 25-28.
} 
firman Allah dan diakonia menjadi pelayanan firman Allah. ${ }^{12}$

\section{Model Teologi Gereja Berbasis Hikmat Pengalaman}

Model teologi gereja berbasis hikmat pengalaman bermuara dari gereja Pantekosta dan Karismatik yang tidak begitu mengutamakan pendekatan biblika dalam pelayananya khususnya berkhotbah atau pengajar. Hamba-hamba Tuhan yang berasal dari bukan pendidikan teologi mencoba melayani atau menggembalakan jemaat dengan pengalaman spiritualnya (pertemuannya dengan Tuhan). Biasanya mereka pendidikan teologi hanya berasal dari pendidikan kaum awam yang diadakan di gereja. ${ }^{13}$ Gereja berdasarkan pengalaman menggambarkan dua kegiatan adalah: gereja sebagai tempat untuk beribadah (berupa gedung atau bangunan) dan Gereja sebagai suatu persekutuan umat (kumpulan umat beriman).

Model Teologi Gereja Berbasis Trendtrend Budaya Masa Kini Model Teologi Gereja Berbasis trend-trend masa kini berkaitan dengan perkembangan budaya. Semakin pesat dan rumit budaya semakin berkembangan teologi tersebut. Budaya atau kebudayaan

\footnotetext{
${ }^{12}$ E.G. Singgih, "Pelayanan Gereja yang Kontekstual di Indonesia pada permulaan Milenium III"; Gema, Edisi 57 (2001).

${ }^{13}$ Ditemukan di lapangan bahwa banyak hamba Tuhan yang menggunakan pelayananya berdasarkan pengalamannya mencoba melengkapi
}

merupakan bentuk jamak dari buddhi (budi atau akal) diartikan sebagai hal-hal yang berkaitan dengan budi, dan akal manusia. Jadi Teologi berbasis trend-trend berkaitan dengan budi dan akal manusia. Apalagi sejak teknologi berkembang dengan pesat maka trend-trend ibadah mulai semakin terlihat dengan jelas. Gereja menggunakan fasilitas teknologi untuk pertumbuhan kualitas dan kuantatif gereja tersebut. Teknologi menjadi kekuatan gereja berteologi adalah keseluruhan sarana untuk menyediakan barang-barang yang diperlukan bagi kelangsungan, dan kenyamanan hidup di antara hubungan Allah dengan manusia dan sebaliknya.

Gerakan Model Teologi Gereja berbasis trend-trend melalui teknologi digunakan oleh semua aliran gereja baik Protestan, Pantekosta maupun Karismatik.

\section{Model Teologi Gereja Berbasis "Blessed to be Blessing" \\ Model Teologi Gereja Berbasis "Blessed to be Blessing" berakar dari gerakan Pantekosta dan Karismatik.} Fenomena ini berakar darai ajaran kesembuhan ilahi, mujizat, hidup dalam berkat Tuhan dan lainnya. Dalam perjalanan berjemaat maka banyak gereja

dirinya dengan memberi embel-embel nama belakangnya dengan gelar teologi yang didapat dari kulia instan misalnya: kuliah 2 bulan mendapat gelar S.Th. (sarjana teologi), M.Th. (Magister Teologi) 2 bulan bahkan doktoral diselesaikan tidak lebih dari 3-6 bulan. 
Pantekosta-Karismatik

yang

mengutamakan mengajaran berkat.

Berkat menjadi spiritual bagi kehidupan manusia. Berkat menjadi pemahaman yang sakral dalam agama. Berkat menempatkan diri dalam hubungan antara Allah dengan manusia ciptaan-Nya. Berkat menjadi fenomena dalam gereja dikembangkan oleh gerakan Pantekosta dan Karismatik. Ada yang menyebut fenomena berkat dalam gereja adalah "Teologi Sukses" (Teologi Kemakmuran). ${ }^{14}$

Misalnya di Indonesia khususnya di Gereja Bethany Indonesia menjadi satu fenomena bagi perkembangan berkat tersebut. Pendiri Gereja Bethany Indonesia, Pendeta Abraham Alex Tanuseputra mengatakan bahwa berkat adalah pekerjaan Allah yang dilakukan-Nya untuk tubuh Kristus (gereja) di kayu salib. Segala sesuatu yang dikerjakan Allah di dalam Yesus di atas kayu salib, adalah milik gereja yang adalah tubuh-Nya. Itulah berkat Tuhan yang diberikan kepada orang percaya. Di dalam Yesus ada berkat itu sendiri. ${ }^{15}$

Sukses materi tetapi masuk sorga. Jacob Nahuway, Gembala Sidang Gereja

${ }^{14}$ Herlianto, Teologi Sukses: Antara Allah dan Mamon (Jakarta: BPK Gunung Mulia, 2006) 233. Ia mengatakan bahwa pada satu kutub, khususnya yang berkembang di kalangan Teologi Sukses berpendapat, bahwa hidup yang diberkati Tuhan adalah hidup yang kaya, berkelimpahan, dan tidak kurang suatu apa, sedangkan pada kutub lainnya ada pandangan yang beranggapan bahwa
Mawar Sharon mengatakan sebagai berikut: (1) Sukses itu gagal di mata Allah, jika kita mendewakan kekayaan kita. (2) Sukses itu gagal di mata Allah, jika diperoleh dengan cara yang tidak berkenan kepada allah. (3) Sukses itu gagal, jika sukses yang kita raih membuat kita melupakan Tuhan. (4) Sukses itu gagal, jika tujuan hanya untuk memuaskan keinginan daging. (5) Sukses itu gagal, jika hanya untuk menyimpan di dunia dan tidak menyimpan di sorga. ${ }^{16}$

\section{$\underline{\text { Arah Pengembangan menuju Globalisasi }}$}

Pemahaman Hamba Tuhan tentang Modelmodel Teologi Gereja

Tabel 1 Pemahaman Model-model Teologi Gereja

\begin{tabular}{|l|l|l|}
\hline $\begin{array}{c}\text { Model- } \\
\text { model } \\
\text { Teologi } \\
\text { Bergereja }\end{array}$ & Pemahaman Indikator & Persentase \\
\hline Berbasis & 1. & Gereja yang \\
Filsafat & $\begin{array}{l}\text { mendasarkan } \\
\text { teologinya pada } \\
\text { pemikiran para } \\
\text { filosof-filosof. }\end{array}$ & \\
& 2. $\begin{array}{l}\text { Gereja yang } \\
\text { berdasarkan } \\
\text { logika (akal) }\end{array}$ & $9=21,42 \%$ \\
& 3. $\begin{array}{l}\text { Tidak baik, } \\
\text { karena teologi } \\
\text { filsafat berisi } \\
\text { tentang } \\
\text { pemahamanan } \\
\text { manusia yang } \\
\text { mempercayai } \\
\text { fakta nyata sesuai }\end{array}$ & \\
\hline
\end{tabular}

seorang Kristen yang mau diberkati Tuhan seharusnya hidup miskin, menderita dan prihatin.

$$
{ }^{15} \text { Abraham Alex Tanuseputra, }
$$

Kesembuhan Illahi dan Berkat (Surabaya: House of Blessing, 2005), 42-43.

${ }^{16}$ Jacob Nahuway, Tuhan Ciptakan Kita untuk Sukses (Jakarta: Gereja Bethel Indonesia Jemaat Mawar Sharon Jakarta, 2014), 423-425. 
Excelsis Deo: Jurnal Teologi, Misiologi, dan Pendidikan

\begin{tabular}{|c|c|c|}
\hline & $\begin{array}{l}\text { pada pola piker } \\
\text { atau logika } \\
\text { mereka saja, atau } \\
\text { lebih tepatnya } \\
\text { bahwa teologi } \\
\text { filsafat ini adalah } \\
\text { telogi yang tidak } \\
\text { beralkitabiah. } \\
\text { 4. Gereja berbasis } \\
\text { filsafat adalah } \\
\text { bidat Golongan } \\
\text { ini memandang: } \\
\text { penyaliban Yesus } \\
\text { adalah pura-pura } \\
\text { Tidak paham }\end{array}$ & $\begin{array}{l}3=7,14 \% \\
3=7,14 \%\end{array}$ \\
\hline $\begin{array}{l}\text { Berbasis } \\
\text { Pertobatan } \\
\text { Orang } \\
\text { Murtad }\end{array}$ & $\begin{array}{l}\text { 1. Gereja yang } \\
\text { mendasarkan } \\
\text { teologi focus } \\
\text { kepada } \\
\text { pencaharian dan } \\
\text { pertobatan orang. } \\
\text { 2. Baik, asalkan } \\
\text { orang murtad } \\
\text { yang bertobat itu } \\
\text { benar-benar } \\
\text { dipantau be } \\
\text { pertumbuhannya, } \\
\text { dan setalah orang } \\
\text { yang bertobat itu } \\
\text { telah memiliki } \\
\text { kedewasaan } \\
\text { rohani, maka } \\
\text { orang tersebut } \\
\text { harus diberikan } \\
\text { pelayanan } \\
\text { sebagai tanggung } \\
\text { jawab kepada } \\
\text { Tuhan. yang } \\
\text { Gereja yang suka } \\
\text { mengeksplotir } \\
\text { pentobatan orang } \\
\text { murtad dalam } \\
\text { pelayannya } \\
\text { Gereja yang } \\
\text { mengajarkan } \\
\text { pemulihan hati } \\
\text { (hidup lama } \\
\text { berubah menjadi } \\
\text { hidup baru) } \\
\text { Gereja yang } \\
\text { mendasarkan } \\
\text { teologi bagi } \\
\text { orang yang } \\
\text { bertobat } \\
\text { Gereja sebagai } \\
\text { sarana } \\
\text { pembinaan }\end{array}$ & $12=28,57 \#$ \\
\hline
\end{tabular}

\begin{tabular}{|c|c|c|c|}
\hline & 7. & $\begin{array}{l}\text { orang-orang } \\
\text { Murtad } \\
\text { Tidak paham }\end{array}$ & $9=21,42 \%$ \\
\hline $\begin{array}{l}\text { Berbasis } \\
\text { Politik }\end{array}$ & 1. & 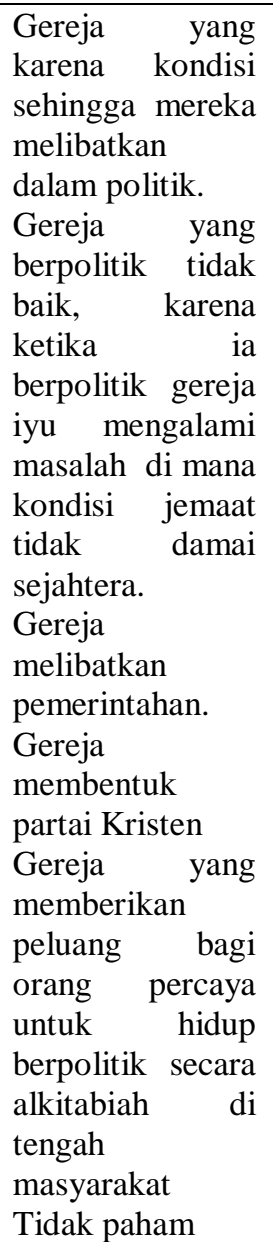 & $\begin{array}{l}3=7,14 \% \\
3=7,14 \% \\
12=28,57 \%\end{array}$ \\
\hline $\begin{array}{l}\text { Berbasis } \\
\text { Pendidikan }\end{array}$ & 1. & $\begin{array}{l}\text { Gereja yang } \\
\text { menekankan } \\
\text { pendidikan untuk } \\
\text { membangun } \\
\text { teologinya. } \\
\text { Gereja } \\
\text { memperdalami } \\
\text { pengetahuan } \\
\text { kebenaran } \\
\text { Firman } \\
\text { Sangat baik } \\
\text { untuk dalam } \\
\text { pertumbuhan } \\
\text { kerohanian } \\
\text { jemaat tetapi } \\
\text { pengenalan akan } \\
\text { Tuhan, itu } \\
\text { pendidikan } \\
\text { wajib berasaal } \\
\text { dari Alkitab. } \\
\text { Gereja yang } \\
\text { menonjolkan } \\
\text { pengetahuan } \\
\text { Gereja yang } \\
\text { menonjokan }\end{array}$ & $\begin{array}{l}3=7,14 \% \\
3=7,14 \%\end{array}$ \\
\hline
\end{tabular}




\begin{tabular}{|c|c|c|c|}
\hline & 6. & $\begin{array}{l}\text { perkembangan } \\
\text { intelektual } \\
\text { Tidak paham }\end{array}$ & $6=14,28 \%$ \\
\hline $\begin{array}{l}\text { Berbasis } \\
\text { Ajaran } \\
\text { Trinitas } \\
\text { (satu Allah } \\
\text { saja: Bapa } \\
\text { yang dari } \\
\text { pada-Nya } \\
\text { berasal } \\
\text { segala } \\
\text { sesuatu dan } \\
\text { yang untuk } \\
\text { Dia kita } \\
\text { hidup, dan } \\
\text { satu Tyhan } \\
\text { saja, yaitu } \\
\text { Yesus } \\
\text { Kristus) }\end{array}$ & 1. & $\begin{array}{l}\text { Gereja yang } \\
\text { menekankan } \\
\text { ketrinitasan } \\
\text { Allah sebagai } \\
\text { pusat teologi. } \\
\text { Teologi yang } \\
\text { benar, karena } \\
\text { Allah hanya satu } \\
\text { yang memiliki } \\
\text { tiga fungsi. } \\
\text { Gereja yang } \\
\text { mengajarkan } \\
\text { Bapa, Anak dan } \\
\text { Ro Kudus adalah } \\
\text { satu pribadi } \\
\text { tunggal yaitu } \\
\text { Tuhan Yesus } \\
\text { Kristus } \\
\text { Tidak paham }\end{array}$ & $15=35,71 \%$ \\
\hline $\begin{array}{l}\text { Berbasis } \\
\text { Keagamaan } \\
\text { Murni }\end{array}$ & & $\begin{array}{l}\text { Gereja yang } \\
\text { membangun } \\
\text { teologi murni } \\
\text { yang } \\
\text { membedakan } \\
\text { atau memisahkan } \\
\text { dengan Negara. } \\
\text { Kurang baik } \\
\text { karena pada } \\
\text { dasarnya semua } \\
\text { agama } \\
\text { mengajarkan } \\
\text { tentang } \\
\text { kebaikaan moral } \\
\text { manusia. } \\
\text { Gereja } \\
\text { berdasarkan pada } \\
\text { nilai keagamaan } \\
\text { secara utuh tanpa } \\
\text { percampuran } \\
\text { budaya, adat } \\
\text { istiadat atau } \\
\text { apapun dari luar. } \\
\text { Gereja yang } \\
\text { mengutamakan } \\
\text { ibadah dan } \\
\text { penyembahan } \\
\text { Gereja yang } \\
\text { sangat fanatic } \\
\text { dengan ajaran- } \\
\text { ajaran tradisi } \\
\text { gereja } \\
\text { Tidak paham }\end{array}$ & $18-4285 \%$ \\
\hline $\begin{array}{l}\text { Berbasis } \\
\text { Misioner }\end{array}$ & & $\begin{array}{l}\text { Gereja yang } \\
\text { membangun } \\
\text { teologinya }\end{array}$ & $12=28,57 \%$ \\
\hline
\end{tabular}

\begin{tabular}{|c|c|c|c|}
\hline & 6. & $\begin{array}{l}\text { berdasarkan pada } \\
\text { amanat agung. } \\
\text { Gereja sudah } \\
\text { baik hanya saja } \\
\text { dalam bermisi } \\
\text { wajib } \\
\text { mempunyai visi } \\
\text { yang jelas adalah } \\
\text { guna } \\
\text { pertumbuhan } \\
\text { gereja. } \\
\text { Gereja yang } \\
\text { berbasis pada } \\
\text { pengutusan dan } \\
\text { penginjilan. } \\
\text { Gereja yang } \\
\text { membawa berita } \\
\text { keselamatan } \\
\text { Gereja yang } \\
\text { menjakau dan } \\
\text { memenangkan } \\
\text { jiwa } \\
\text { Gereja yang } \\
\text { memiliki jiwa } \\
\text { misi }\end{array}$ & $\begin{array}{l}12=28,57 \% \\
3=7,14 \% \\
6=14,28 \% \\
6=14,28 \%\end{array}$ \\
\hline $\begin{array}{l}\text { Berbasis } \\
\text { Teologi } \\
\text { Reformed }\end{array}$ & 1. & $\begin{array}{l}\text { Gereja yang } \\
\text { membangun } \\
\text { teologinya } \\
\text { kembali kepada } \\
\text { kebenaran } \\
\text { Alkitab. } \\
\text { Teologi dapat } \\
\text { membantu para } \\
\text { jemaat memiliki } \\
\text { iman yang teguh } \\
\text { di dalam Tuhan. } \\
\text { Gereja yang } \\
\text { bercorak injili } \\
\text { Gereja yang } \\
\text { menekankan } \\
\text { pada teologi } \\
\text { Calvin yang } \\
\text { Gereja ma yang } \\
\text { mengajarkan } \\
\text { keselamatan } \\
\text { karena anugerah } \\
\text { Gereja yang } \\
\text { mengajarkan } \\
\text { sekali selamat } \\
\text { tetap selamat } \\
\text { Tidak paham }\end{array}$ & $\begin{array}{l}3=7,14 \% \\
15=35,71 \% \\
6=14,28 \%\end{array}$ \\
\hline $\begin{array}{l}\text { Berbasis } \\
\text { Pentakost-a }\end{array}$ & & $\begin{array}{l}\text { Gereja yang } \\
\text { membangun } \\
\text { teologinya } \\
\text { berdasarkan pada } \\
\text { gerakan Roh } \\
\text { Kudus dalam } \\
\text { pertumbuhan } \\
\text { gereja. }\end{array}$ & $15=35,71 \%$ \\
\hline
\end{tabular}




\begin{tabular}{|c|c|c|}
\hline & 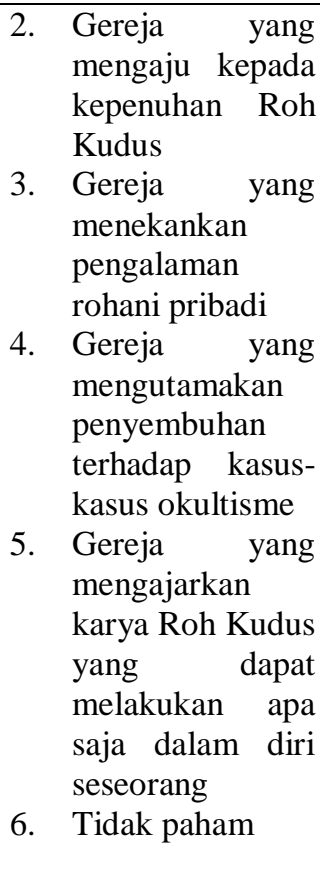 & $3=7,14 \%$ \\
\hline $\begin{array}{l}\text { Bebasis } \\
\text { Karismati-k }\end{array}$ & $\begin{array}{l}\text { 1. Gereja yang } \\
\text { membangun } \\
\text { teologinya pada } \\
\text { gerakan jaman } \\
\text { baru (Roh Kudus, } \\
\text { puji-pujian dan } \\
\text { penyembahan). } \\
\text { 2. Baik, dengan } \\
\text { bahasa lidah } \\
\text { jemaat dapat } \\
\text { berhubungan } \\
\text { khusus dengan } \\
\text { Tuhan. } \\
\text { Gereja berbasis } \\
\text { kepada karunia } \\
\text { Roh } \\
\text { Gereja yang } \\
\text { berbasis karya } \\
\text { Roh Kudus } \\
\text { melalui nubuat } \\
\text { dan mujizat } \\
\text { Tidak paham. }\end{array}$ & $\begin{array}{l}12=28,57 \% \\
6=14,28 \%\end{array}$ \\
\hline $\begin{array}{l}\text { Berbasis } \\
\text { Oikumenis } \\
\text { me }\end{array}$ & $\begin{array}{l}\text { 1. Gereja yang } \\
\text { mendasarkan } \\
\text { pada teologinya } \\
\text { pada } \\
\text { kebersamaan dari } \\
\text { gereja-gereja dan } \\
\text { universalisme. } \\
\text { 2. Baik karena } \\
\text { teologi ini } \\
\text { berusaha } \\
\text { menyatukan } \\
\text { orang-otang } \\
\text { Kristen berbagai } \\
\text { denominasi. } \\
\text { Gereja yang } \\
\text { bersekutu dengan }\end{array}$ & $9=21,42 \%$ \\
\hline
\end{tabular}

\begin{tabular}{|c|c|c|c|}
\hline & 4. & $\begin{array}{l}\text { gereja-gereja } \\
\text { lain. } \\
\text { Gereja yang } \\
\text { mengacu pada } \\
\text { persatuan gereja. } \\
\text { Tidak paham }\end{array}$ & $\begin{array}{l}15=35,71 \% \\
6=14,28 \%\end{array}$ \\
\hline $\begin{array}{l}\text { Berbasis } \\
\text { Pendidik-an } \\
\text { sebagai } \\
\text { Proses } \\
\text { jemaat } \\
\text { Berteologi }\end{array}$ & 1. & $\begin{array}{l}\text { Gereja yang } \\
\text { memberdayakan } \\
\text { jemaat untuk } \\
\text { belajar Alkitab } \\
\text { dalam berteologi. } \\
\text { Gereja } \\
\text { berdasarkan } \\
\text { pendidikan untuk } \\
\text { bertumbuh. } \\
\text { Tidak paham }\end{array}$ & $12=28,57 \%$ \\
\hline $\begin{array}{l}\text { Berbasis } \\
\text { Tridarma } \\
\text { Gereja } \\
\text { (Koinonia = } \\
\text { bersekutu, } \\
\text { marturia = } \\
\text { bersaksi dan } \\
\text { diakonia = } \\
\text { pelayanan) }\end{array}$ & 1. & $\begin{array}{l}\text { Gereja yang } \\
\text { berteologi } \\
\text { mendasarkan } \\
\text { tridarma perlu } \\
\text { keseimbangan } \\
\text { ketiganya. } \\
\text { Gereja yang lebih } \\
\text { membangun } \\
\text { semangat gereja } \\
\text { untuk bersekutu } \\
\text { dalam Tuhan. } \\
\text { Tidak paham }\end{array}$ & $15=35,71 \%$ \\
\hline $\begin{array}{l}\text { Berbasis } \\
\text { Pengalam- } \\
\text { an (Hikmat } \\
\text { Pengalaman } \\
\text { ) }\end{array}$ & 1. & $\begin{array}{l}\text { Pengalaman } \\
\text { pribadinya } \\
\text { sebagai pusat } \\
\text { berteologi } \\
\text { sehingga } \\
\text { pusatnya pada } \\
\text { pengalaman dan } \\
\text { selanjutnya tiap- } \\
\text { tiap orang bisa } \\
\text { berbeda dalam } \\
\text { berteologi. } \\
\text { Kurang baik, } \\
\text { karena hamper } \\
\text { menyerupai } \\
\text { teologi filsafat di } \\
\text { mana seseorang } \\
\text { hanya tidak } \\
\text { mempercayai } \\
\text { Tuhan dengan } \\
\text { kenyataan yang } \\
\text { penah mereka } \\
\text { alami saja. } \\
\text { Pengalaman } \\
\text { tidak sama } \\
\text { dengan Firman } \\
\text { Allah. Percaya } \\
\text { pengalaman } \\
\text { berarti } \\
\text { percaya Firman } \\
\text { Allah. } \\
\text { Pengalaman } \\
\text { pribadi gembala }\end{array}$ & $12=28,57 \%$ \\
\hline
\end{tabular}




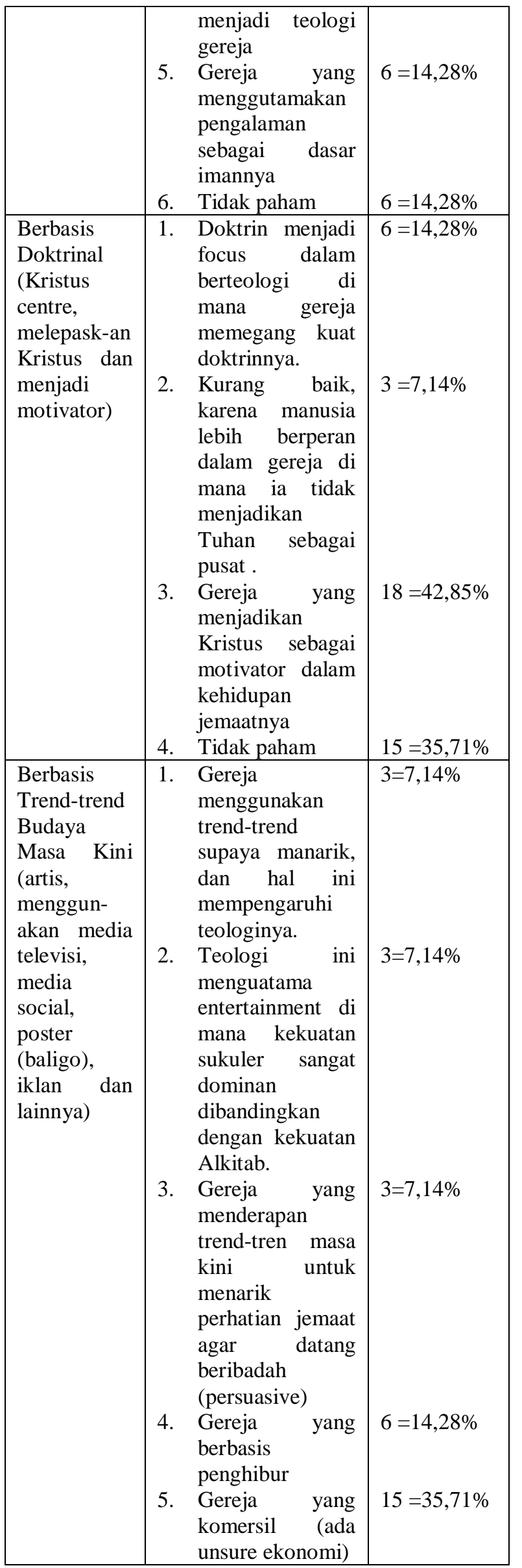

\begin{tabular}{|c|c|c|}
\hline & $\begin{array}{ll}\text { 6. } & \text { Gereja yang } \\
\text { menggunakan } \\
\text { media Teknologi } \\
\text { 7. Gereja yang } \\
\text { menggutakan } \\
\text { budaya modern } \\
\text { sebagai dasar } \\
\text { pengajarannya } \\
\text { 8. } \\
\text { Tidak paham }\end{array}$ & $6=14,28 \%$ \\
\hline $\begin{array}{l}\text { Berbasis } \\
\text { "Blessed" } \\
\text { (diberkati) } \\
\text { dan } \\
\text { "Blessing" } \\
\text { (member- } \\
\text { kati) }\end{array}$ & 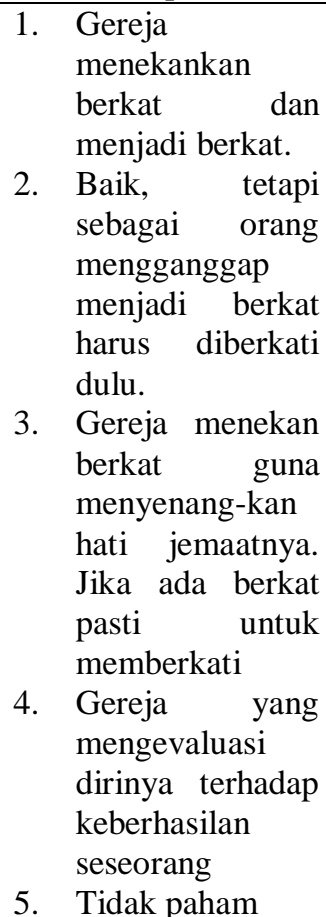 & $9=21,42 \%$ \\
\hline
\end{tabular}

Dari tabel di atas dapat disimpulkan bahwa tingkat pemahaman hamba Tuhan terhadap model-model teologi gereja sebagai berikut: Pertama, model-model teologi yang dipahami hamba Tuhan adalah model-model teologi berbasis filsafat (57,14\%), berbasis Pendidikan (50\%), berbasis "bless to be s blessing" (50\%), berbasis Ajaran Trinitas (42,85\%) dan berasis Doktrin $(42,85) \%$. Kedua, pendalaman pemahaman model-model teologi hamba Tuhan sebagai berikut: Model-model Teologi Berbasis Filsafat adalah Gereja yang mendasarkan teologinya pada pemikiran para filosof- 
filosof $57,14 \%$, berbasis pertobatan orang murtad adalah gereja yang Gereja yang mengajarkan pemulihan hati (hidup lama berubah menjadi hidup baru) 28,57\%, berbasis politik adalah Gereja yang memberikan peluang bagi orang percaya untuk hidup berpolitik secara alkitabiah di tengah masyarakat 28,5\%, berbasis Pendidik adalah Gereja yang menekankan pendidikan untuk membangun teologinya. 50\%, berbasis Ajaran Trinitas adalah tidak paham $42,85 \%$, berbasis keagamaan murni adalah gereja berdasarkan pada nilai keagamaan secara utuh tanpa percampuran budaya, adat istiadat atau apapun dari luar $21,42 \%$, . berbasis missioner adalah : (1) Gereja yang membangun teologinya berdasarkan pada amanat agung. 28,5\% dan (2) Gereja yang berbasis pada pengutusan dan penginjilan. 28,5 , berbasis teologi Reformed adalah Gereja yang mengajarkan sekali selamat tetap selamat $35,71 \%$, berbasis Pentakosta adalah: (1) Gereja yang membangun teologinya berdasarkan pada gerakan Roh Kudus dalam pertumbuhan gereja $35,71 \%$ dan (2) Gereja yang mengaju kepada kepenuhan Roh Kudus $35,71 \%$, berbasis Karismatik adalah Gereja yang membangun teologinya pada gerakan jaman baru (Roh Kudus, puji-pujian dan penyembahan) $\quad 35,71 \%$, berbasis Oikumenisme adalah Gereja yang mengacu pada persatuan gereja $35,71 \%$, berbasis Pendidikan sebagai proses jemaat
Berteologi adalah Gereja yang memberdayakan jemaat untuk belajar Alkitab dalam berteologi $42,85 \%$, berbasis Tridarma Gereja adalah tdaik paham $35,71 \%$, berbasis Hikmat Pengalaman adalah Pengalaman pribadi gembala menjadi teologi gereja $28,57 \%$, berbasis Doktrinal adalah Gereja yang menjadikan Kristus sebagai motivator dalam kehidupan jemaatnya $42,85 \%$, berbasis Trend-trend Budaya Masa Kini adalah Gereja yang komersil (ada unsur ekonomi) 35,71\%, dan berbasis "Blessed" (diberkati) dan "Blessing" (memberkati) adalah Gereja menekankan berkat dan menjadi berkat $50 \%$.

\section{Model Teologi yang Digunakan Hamba} Tuhan dalam Pelayanannya

Tabel 2 Model Teologi yang Digunakan Hamba Tuhan dalam Pelayanannya

\begin{tabular}{|c|c|c|}
\hline \multirow{5}{*}{$\begin{array}{l}\text { Apakah } \\
\text { Model } \\
\text { Teologi } \\
\text { yang saya } \\
\text { gunakan } \\
\text { dalam } \\
\text { Pelayanan } \\
\text { saya? }\end{array}$} & Jawaban & Persentase \\
\hline & $\begin{array}{l}\text { 1. Gereja yang } \\
\text { berbasis } \\
\text { missioner dan } \\
\text { mendasarkan } \\
\text { pada misi } \\
\text { Alkitab }\end{array}$ & $9=15,78 \%$ \\
\hline & 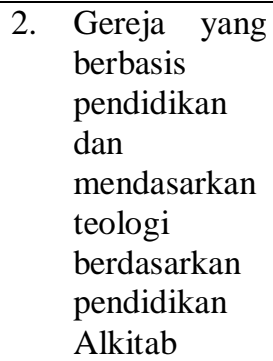 & $9=15,78 \%$ \\
\hline & $\begin{array}{l}\text { 3. Gereja } \\
\text { campuran: } \\
\text { berbasis } \\
\text { Tridarma dan } \\
\text { Trinitas }\end{array}$ & $9=15,78 \%$ \\
\hline & $\begin{array}{ll}\text { 4. } & \text { Gereja } \\
\text { berbasis }\end{array}$ & $6=10,5 \%$ \\
\hline
\end{tabular}




\begin{tabular}{|c|c|c|}
\hline & $\begin{array}{l}\text { Tridarma } \\
\text { Gereja }\end{array}$ & \\
\hline & $\begin{array}{l}\text { Gereja } \\
\text { berbasis } \\
\text { Pentakosta }\end{array}$ & $3=5,26 \%$ \\
\hline & $\begin{array}{l}\text { Gereja } \\
\text { Karismatik }\end{array}$ & $3=5,26 \%$ \\
\hline & $\begin{array}{l}\text { Gereja } \\
\text { campuran: } \\
\text { berbasis } \\
\text { Pendidikan, } \\
\text { Missioner } \\
\text { dan } \\
\text { Reformasi }\end{array}$ & $3=5,26 \%$ \\
\hline & $\begin{array}{l}\text { Gereja yang } \\
\text { berbasis } \\
\text { Reformasi } \\
\text { dan } \\
\text { mendasarkan } \\
\text { teologi pada } \\
\text { Alkitab }\end{array}$ & $3=5,26 \%$ \\
\hline & $\begin{array}{l}\text { Gereja } \\
\text { berbasis } \\
\text { Oikumenism } \\
\mathrm{e}\end{array}$ & $3=5,26 \%$ \\
\hline & $\begin{array}{l}\text { Gereja } \\
\text { campuran: } \\
\text { berbasis } \\
\text { "bless dan } \\
\text { blessing" } \\
\text { dengan } \\
\text { berbasis } \\
\text { Karismatik }\end{array}$ & $3=5,26 \%$ \\
\hline & Tidak paham & $6=10,5 \%$ \\
\hline
\end{tabular}

Dari tabel di atas dapat ditemukan bahwa model-model teologi gereja yang digunakan oleh gereja-gereja di Indonesia sebagai berikut: (1) Gereja yang berbasis missioner dan mendasarkan pada misi Alkitab (15,78\%), Gereja yang berbasis pendidikan dan mendasarkan teologi berdasarkan pendidikan Alkitab $(15,78)$ dan Gereja campuran: berbasis Tridarma dan Trinitas (15,78\%) (2) Gereja berbasis Tridarma Gereja (10,5\%).
Manfaat bagi Dirinya Sendiri terhadap Model Teologi yang Digunakan Hamba Tuhan dalam Pelayanannya

Tabel 3 Manfaat bagi Dirinya Sendiri terhadap Model Teologi yang Digunakan Hamba Tuhan

\begin{tabular}{|c|c|c|}
\hline \multirow{48}{*}{$\begin{array}{l}\text { Sejauhmanak } \\
\text { ah manfaat } \\
\text { Model } \\
\text { Teologi } \\
\text { Gereja yang } \\
\text { saya layani } \\
\text { bagi } \\
\text { pertumbuhan } \\
\text { imannya } \\
\text { sendiri? }\end{array}$} & Jawabannya & Persentasi \\
\hline & \multirow{3}{*}{$\begin{array}{l}\text { 1. Bermanfaat } \\
\text { untuk } \\
\text { pertumbuhan }\end{array}$} & \multirow{13}{*}{$9=15 \%$} \\
\hline & & \\
\hline & & \\
\hline & iman karena & \\
\hline & dengan & \\
\hline & mendasarkan & \\
\hline & pada hal-hal & \\
\hline & yang benar, & \\
\hline & ada kondisi & \\
\hline & yang & \\
\hline & signifikkan & \\
\hline & jemaat & \\
\hline & $\begin{array}{l}\text { bertumbuh } \\
\text { kearah Kristus }\end{array}$ & \\
\hline & 2. Saya semakin & $6=10 \%$ \\
\hline & mengerti akan & \\
\hline & Firman & \\
\hline & Tuhan. & \\
\hline & 3. Saya & $3=5 \%$ \\
\hline & membantu & \\
\hline & memiliki sifat & \\
\hline & yang tegas & \\
\hline & dalam & \\
\hline & memutuskan & \\
\hline & suatu & \\
\hline & keputusan & \\
\hline & tanpa iming- & \\
\hline & iming dari & \\
\hline & orang lain. & \\
\hline & 4. Saya mampu & $3=5 \%$ \\
\hline & mengatasi & \\
\hline & beberapa & \\
\hline & masalah yang & \\
\hline & besar dalam & \\
\hline & persekutuan & \\
\hline & gereja & \\
\hline & 5. Saya dapat & $3=5 \%$ \\
\hline & belajar & \\
\hline & menyiapkan & \\
\hline & diri untuk & \\
\hline & menlayani & \\
\hline & jemaat. & \\
\hline & 6. Membantu & $3=5 \%$ \\
\hline & saya memiliki & \\
\hline & sifat hormat & \\
\hline & terhadap & \\
\hline & beberapa & \\
\hline & gereja lain & \\
\hline & yang & \\
\hline
\end{tabular}




\begin{tabular}{|c|c|}
\hline $\begin{array}{l}\text { bergabung di } \\
\text { dalamnya }\end{array}$ & \\
\hline $\begin{array}{l}\text { 7. Saya dapat } \\
\text { memberikan } \\
\text { pengajaran } \\
\text { yang benar } \\
\text { kepada jemaat }\end{array}$ & $3=5 \%$ \\
\hline $\begin{array}{l}\text { 8. Saya terbuka } \\
\text { bahwa gereja } \\
\text { ibarat bengkel } \\
\text { untuk mau } \\
\text { terbuka } \\
\text { membekali, } \\
\text { memberkati, } \\
\text { terbuka dan } \\
\text { melengkapi }\end{array}$ & $3=5 \%$ \\
\hline $\begin{array}{l}\text { 9. Saya dapat } \\
\text { menolong } \\
\text { orang untuk } \\
\text { bertumbuh } \\
\text { imanya } \\
\end{array}$ & $3=5 \%$ \\
\hline $\begin{array}{l}\text { 10. Saya dapat } \\
\text { bersaksi } \\
\text { tentang } \\
\text { Kristus } \\
\end{array}$ & $3=5 \%$ \\
\hline $\begin{array}{l}\text { 11. Saya setia } \\
\text { mengikuti } \\
\text { Tuhan }\end{array}$ & $3=5 \%$ \\
\hline \begin{tabular}{|l|} 
12. Saya \\
diberkati oleh \\
Tuhan \\
\end{tabular} & $3=5 \%$ \\
\hline 13. Tidak paham & $15=25 \%$ \\
\hline
\end{tabular}

Dari tabel di atas dapat disimpulkan bahwa adanya model-model teologi gereja dapat mempertumbuhkan iman hamba Tuhan dalam bentuk sebagai berikut: (1) Bermanfaat untuk pertumbuhan iman karena dengan mendasarkan pada hal-hal yang benar, ada kondisi yang signifikkan jemaat bertumbuh kea rah Kristus (15\%) dan (2) Saya semakin mengerti akan Firman Tuhan (10\%).
Pengimplikasian Model Teologi yang Digunakan Hamba Tuhan kepada Jemaat Gereja

Tabel 4 Pengimplikasian Model Teologi yang Digunakan Hamba Tuhan kepada Jemaat Gereja

\begin{tabular}{|c|c|c|}
\hline \multirow{9}{*}{\begin{tabular}{lr}
\multicolumn{2}{l}{ Sejauhmanakah } \\
Saya & dapat \\
mengimplikasik \\
an & Model \\
Teologi & gereja \\
saya & kepada \\
jemaat & Gereja \\
agar & iman \\
semakin & \\
bertumbuh?
\end{tabular}} & $\begin{array}{l}\text { Jawabannya } \\
\text { 1. } \\
\text { Saya dapat } \\
\text { pengajaran } \\
\text { Alkitab } \\
\text { secara rutin. }\end{array}$ & $\frac{\text { Persentasi }}{9=15,78 \%}$ \\
\hline & $\begin{array}{ll}\text { 2. } & \text { Saya dapat } \\
& \text { melakukan } \\
\text { pemuridan } \\
\text { dengan baik }\end{array}$ & $6=10,5 \%$ \\
\hline & $\begin{array}{l}\text { 3. Saya dapat } \\
\text { membina } \\
\text { iman jemaat }\end{array}$ & $6=10,5 \%$ \\
\hline & $\begin{array}{l}\text { 4. Saya } \\
\text { memahami } \\
\text { dan dapat } \\
\text { mempraktek } \\
\text { an Firman } \\
\text { Tuhan } \\
\text { dengan baik }\end{array}$ & $6=10,5 \%$ \\
\hline & $\begin{array}{l}\text { 5. Saya dapat } \\
\text { menumbuhk } \\
\text { an iman } \\
\text { jemaat } \\
\text { melalui } \\
\text { teologi yang } \\
\text { dibangun } \\
\end{array}$ & $6=10,5 \%$ \\
\hline & $\begin{array}{ll}\text { 6. } & \text { Saya } \\
& \text { menjadi } \\
\text { teladan bagi } & \text { jemaat } \\
\end{array}$ & $6=10,5 \%$ \\
\hline & $\begin{array}{l}\text { 7. Saya dapat } \\
\text { mengimplik } \\
\text { asijan model } \\
\text { teologi } \\
\text { hanya } \\
\text { sebatas } \\
\text { kegiatan } \\
\text { dalam gereja }\end{array}$ & $3=5,26 \%$ \\
\hline & $\begin{array}{ll}\text { 8. } & \text { Saya } \\
\text { menjadi } \\
\text { saluran } \\
\text { berkat bagi } \\
\text { jemaat }\end{array}$ & $3=5,26 \%$ \\
\hline & $\begin{array}{ll}\text { 9. } & \text { Tidak } \\
\text { paham }\end{array}$ & $12=21 \%$ \\
\hline
\end{tabular}

Tabel di atas dapat didimpulkan bahwa dengan adanya model teologi gereja, maka hamba Tuhan dapat menumbuhkan 
iman jemaat dalam bentuk: (1) Saya dapat pengajaran Alkitab secara rutin $(15,78 \%)$, (2) Saya dapat melakukan pemuridan dengan baik (10,5\%), Saya dapat membina iman jemaat (10,5\%), Saya memahami dan dapat mempraktekan Firman Tuhan dengan baik $(10,5 \%)$, Saya dapat menumbuhkan iman jemaat melalui teologi yang dibangun $(10,5 \%)$ dan Saya menjadi teladan bagi jemaat $(10,5 \%)$.

\section{Arah Model-model Teologi Gereja di Gereja-Gereja Indonesia}

Dari perkembangan model-model teologi gereja di atas dapat dilihat arah perkembangan model-model teologi dari berbasis Filsafat hingga berbasis "Blessed to be a Blessing" sebagai berikut:

\section{Arah Model-model Teologi Gereja}

\section{Berkembang}

Arah perkembangan model-model teologi gereja yang semula berbasis model teologi filsafat berkembang hingga memasuki abad 21 kini ditemukan beberapa model teologi gereja sebagai berikut: (1) perkembangan model teologi gereja dari berbasis filsafat, berbasis pertobatan orang murtad, berbasis ajaran Trinitas, berbasis politik, berbasis pendidikan, berbasis keagamaan murni, berbasis misioner, berbasis Teologi Protestan (Reformed), berbasis Pantekosta, berbasis Karismatik, berbasis Oikumenisme, berbasis pendidikan sebagai proses jemaat berteologi, berbasis tridarma gereja, berbasis hikmat pengalaman, berbasis trend-trend budaya masa kini hingga berbasis "Bless to be a Blessing". (2) Model-model teologi gereja berbasis Protestan, Pantekosta dan Karismatik tetap menjadi gambaran dasar model-model teologi gereja. Tetapi, dalam perkembangannya terjadi pergeseran di mana model-model tersebut dilengkapi dengan model teologi gereja berbasis: Misioner, Pendidikan, Tridarma Gereja dan Ajaran Trinitas. Tetapi, bagi konteks Indonesia, perkembangan model-model teologi gereja bergerak ke arah berbasis adalah: Missioner, Pendidikan, Tridarma Gereja, Ajaran Trinitas bahkan campuran antara basis Tridarma Gereja dan Ajaran Trinitas, Oikumenisme dan "Bless to be a Blessing". (3) Sementara hamba Tuhan menolak mengikuti model teologi gereja seperti: berbasis filsafat, berbasis pertobatan orang murtad, berbasis politik, berbasis hikmat pengalaman dan berbasis trend-trend budaya masa kini meskipun model-model teologi tersebut sudah dipraktekkan dalam gerejanya.

Keterbatasan Hamba Tuhan untuk Berteologi Arah perkembangan model teologi gereja membuat hamba Tuhan sebagai berikut: (1) hamba Tuhan mempunyai pemahaman yang "sedang" (antara 42$50 \%$ terhadap model-model teologi 
berbasis filsafat $(57,14 \%), \quad$ berbasis Pendidikan (50\%), berbasis "bless to be $\mathrm{s}$ blessing" (50\%), berbasis Ajaran Trinitas $(42,85 \%)$ dan berasis Doktrin $(42,85) \%)$ sedangkan pemahaman yang lain adalah “kurang" (di bawah 42\%) terhadap berbagai model teologi gereja. (2) Hamba Tuhan mempunyai sikap "malu-malu dan tidak tegas" dengan model teologi gereja yang dianut gerejanya. Mereka menolak bila dikatakan mereka menganut model teologi yang berbasis filsafat, berbasis politik atau berbasis trend-trend budaya masa kini bahkan mereka "menolak dengan ragu-ragu" kalau model teologi gerejanya adalah "bless to be a blessing". (3) hamba Tuhan menyadari pentingnya model-model teologi yang berjalan di gerejanya. Alasanya adalah model-model teologi gereja dapat memampukan dirinya mengenal firman Tuhan, merubah dirinya dari kehidupan lama menjadi baru, mempraktekkan dalam kehidupannya dan dapat digunakan sebagai dasar pembinaan iman jemaat. Dengan demikian, bila model teologi gereja yang dianut berbasis yang "kurang tepat" maka akan mempengaruhi pertumbuhan iman hamba Tuhan dan jemaatnya, serta pertumbuhan kualitas dan kuantitas gereja itu sendiri.

\section{KESIMPULAN}

Keputusan untuk memilih model teologi gereja bukanlah keputusan yang gampang bagi sebuah gereja karena gereja sudah dibentengi oleh nilai-nilai Kristus yang diwujudkan dalam Alkitab. Nilai-nilai Alkitab yang akhirnya menjadi doktrin dalam kualitas dan kuantitas pertumbuhan gereja. Sementara perkembangan globalisasi semakin dekat di hati, jelas dan dapat dimasuki setiap saat bila seseorang ingin masuk sehingga kekuatan globalisasi seolah-olah menekan model teologi sebuah gereja. Gereja bersikap: apakah menolak globalisasi, masuk hanyut dalam proses globaliasi atau kompromi dengannya. Di sinilah model teologi gereja dapat ditentukan: tetap bertahan, menolak atau beradaptasi.

\section{DAFTAR PUSTAKA}

Culver, John. Sejarah Penginjilan Sedunia. Bandung: Institut Alkitab Tiranus, 1997.

Herlianto, Teologi Sukses: Antara Allah dan Mamon. Jakarta: BPK Gunung Mulia, 2006.

Nahuway, Jacob. Tuhan Ciptakan Kita untuk Sukses. Jakarta: Gereja Bethel Indonesia Jemaat Mawar Sharon Jakarta, 2014.

Saerang, Joppy A. "Oikumene dan Pemahamannya menurut Alkitab"; Jurnal Pelita Zaman. Vol. 1. No. 1 (1986).

Singgih, E. G. "Pelayanan Gereja yang Kontekstual di Indonesia pada permulaan Milenium III"; Gema, Edisi 57 (2001).

Singgih, E.G. Reformasi dan Transformasi 
Pelayanan Gereja Menyongsong Abad ke-21. Yogyakarta: Kanisius, 1997.

SJ, John Willis. The Teachings of the Church Fathers. San Francisco: Ignatius Press, 2002.

Song, Choan-Seng. Sebutkanlah Namanama Kami. Jakarta: Gunung Mulia, 1989.

St. Ignatius of Antiokh, Letter to the Ephesians, Chap 9.

Sumual, Nicky J. Pantekosta Indonesia. Manado: Nicky J. Sumual, 1981.

Tanuseputra, Abraham Alex. Kesembuhan Illahi dan Berkat. Surabaya: House of Blessing, 2005.

Wongso, Peter. Hamba Tuhan dan jemaat Kristus yang Melintasi Zaman. Malang: SAAT, 2002.

Yoder, John H. The Politics of Jesus. Grand Rapids: William B. Eerdmans Publishing Company, 1979 